\title{
Listening Class Distance Learning for German BIPA Students
}

\author{
Novietri
}

IPB University

Email: veenovietri@gmail.com

\begin{abstract}
The pandemic situation had an impact on the program of sending foreign students to Indonesia for learning Bahasa Indonesia (BIPA). One of them is the students of HTWG from Konstanz, Germany. This situation, consequently, makes BIPA learning process should be carried out online. The listening class of Bahasa Indonesia, in particular, requires specific strategies so that the virtually face-to-face learning activities can be as effective as the offline one. During the distance learning of listening class, learning activities were assisted with several applications, namely WhatsApp, Zoom, Google Form, Edpuzzle, and Padlet. This study reveals that these applications indeed were very helpful during the learning activities. However, there are some issues in the distance learning implementation. Eventually, the virtual faceto-face learning cannot completely replace the offline listening class of Bahasa Indonesia.
\end{abstract}

\section{Keywords: Bahasa Indonesia, BIPA, Listening, Distance Learning}

\section{INTRODUCTION}

Many countries have established the Indonesian Language Learning for Foreign Speakers (BIPA) program. If we look at the BIPA web page of the Ministry of Education and Culture [1], there are already hundreds of foreign institutions that have organized BIPA programs for their citizens. These countries include Australia, the United States, France, Germany, Thailand and Egypt. Based on the bipa.kemdikbud web page, Australia already has 112 institutions that provide BIPA study programs. While Germany has 19, Thailand has 43 institutions. It proves that there are significant amount of foreigners interested in learning Bahasa Indonesia.

The phenomenon of BIPA learning in Indonesia itself proves that there are many enthusiasts in learning Bahasa Indonesia. Various institutions, such as schools and universities, offer some good cooperative programs to attract foreign learners. Therefore, this learning program can be performed continuously. A form of cooperation that can be established is sending students from their institution to continue their learning directly in Indonesia.

HTWG Konstanz, Germany, is one of the universities that have BIPA learning program. In 2020, HTWG Konstanz has a summer program to send students to learn in Indonesia. However, at the same time, a pandemic outbreak occurred worldwide, including in Indonesia. Citizens are prohibited from entering and leaving Indonesia, including Germany. Therefore, a Distance Learning Program (hereinafter referred to as PJJ) is created. This program collaborates with the State University of Jakarta and APPBIPA (Affiliation of
Indonesian Language Teachers and Activists for Foreign Speakers).

Language learning for BIPA classes focuses on four skills, which are reading, writing, listening, and speaking. During the pandemic, PJJ remains focused on these four skills. All learning activities are carried out by the Indonesian teachers by using various online applications to facilitate PJJ.

This study will focus on listening skill. It aims to explore the effective listening learning strategies and to examine the effectiveness during PJJ and the applications used in BIPA class. This study use qualitative method. Creswell [2] expressed that there are several characteristic in qualitative research, the researchers collect data through documentation, behavioral observation, or interviews; the researchers will focus on studying problems or issues presented by the participants and make interpretations from what they seen, heard, and learned. In this study, the data were collected from the observations during class activity and from questionnaires in order to identify the learner needs and difficulties in learning. Documentation also conducted to study and observe the process during PJJ in listening class.

The data in this study gathered from HTWG Konstanz students during PJJ. Due to the pandemic, not all BIPA learners were able to participate in PJJ. Therefore, the participants were students with different skill levels. There are 8 Konstanz students that participated in this PJJ. One of them stays in Lombok, Indonesia. When the pandemic hits the world, he still not returns to Germany yet. Out of eight students, one student only took the listening class twice. Therefore, there were 
only 7 participants in this survey. Their age ranged from 22-29 years old. Their previous learning experience also varies; ranged from 2 to 5 years. Only one of these students had never visited Indonesia. Thus, they all joined the BIPA class of B1 level.

The PJJ was conducted for two weeks, from August 10 to August 21 in 2020 . The meeting schedule is in the weekdays, Monday-Friday. They learned two skills each day - for example, on the first day they will learn Reading and Writing skills, on the second day they will learn Listening and Speaking skills. The allocated time for each skill is 90 minutes or one and a half hours. Therefore, the total meetings for the Listening class is five meetings, or for 450 minutes. The last meeting on 22 August was the final exam and the students represent their paper. This exam covers every skills, therefore is not included in the data.

The teacher surveyed the class twice, at the end of the class on the first day and on the last day after the exam. The data were collected by giving questionnaire that filled out by the students. This study is expected to provide an overview and initial information on the effectiveness of PJJ on Listening class for BIPA students.

\section{DISCUSSION}

\subsection{Online Methods and Mobile Applications}

Indonesian Language Learning for Foreign Speakers (BIPA) is different from Indonesian Language Learning for Indonesian. At formal schools in Indonesia, students learn Bahasa Indonesia as a subject that focused on comprehension because it is their daily language or their first language. BIPA Learning is more complex and complicated [3]. As well as in getting to know a language, the material will focus on communication skills. Therefore, in the preparation, many aspects need to be considered.

According to Muliastuti [3], there are no learning materials or textbooks, including learning methods, which are ideal for BIPA learners to use. A textbook used by a teacher not necessarily can be used by other teacher. Each teacher needs a different approach and textbook. Each method also has advantages and disadvantages. Therefore, BIPA teachers must find the appropriate materials and learning methods based on BIPA students' background.

Listening teaching materials on the five meetings for Konstanz students were divided based on the topic. The topics in this listening activity were professions, legend story on tourist attractions site, news on craft entrepreneurs, interviews on digital economy, and the presentation of research findings. The teaching materials were in audio and video forms, shared through online applications.
In order to examine the learning method in listening class, this study conducted through question and answer method. Anas [4] explained that the question and answer method is a way of delivering a lesson through two-way interaction between teacher and students in order to obtain answers on the material's comprehension. The questioning strategy is useful for knowing to what extent the learners comprehend the lesson. The question and answer method in Listening class applied by providing video or audio in Bahasa Indonesia. After they listen to the audio or video, the students will answer some questions based on the materials they had listened to. The answers will show their comprehension level to the material.

PJJ not only requires internet connection, but also a variety of online-platform applications to facilitate the learning process. Currently, there are various online applications available. We can also learn how to use each of them easily from tutorials on the internet. In PJJ Class for German BIPA Students, the applications some application were used, which are WhatsApp, Zoom, Google Form, Edpuzzle, and Padlet.

\section{WhatsApp}

WhatsApp is an instant messaging app for mobile phones. This app requires internet data. WhatsApp was founded in 2009 in California, [5] by Jan Koum and Brian Acton, who previously worked at Yahoo!. Based on the information on the WhatsApp page [6], this app could send and receive texts, photos, videos, documents, locations to voice calls. It provides some features; one of them is to create group chats. This feature can be utilized to connect students and allow them to share information and material for learning. In addition, the students also use voice message sharing feature to record voice message for working on specific tasks.

\section{Zoom}

Zoom is an online communication service that allows its users to use videos. It was founded in 2011 and based in San Jose, California, United States [7]. It is widely used in various organizations and companies to facilitate online meetings, video conferences. This app also can be used on mobile and desktop devices. The advantages in using this app is the ability to host meeting for hundreds participant in HD video and audio which can be recorded and automatically stored on the user desktop. It also allows the users to schedule the meeting, send messages to all participants or individuals, share screen, and create separate rooms (breakout rooms feature). Due to its advantages, Zoom was chosen to support BIPA class. Before every meeting, teacher will send the meeting schedule and a link via WhatsApp group chats. This link includes the meeting ID and passcode for students to join the Zoom Meetings. 


\section{Google Form}

Google Form is an app for creating surveys or quizzes. Google Form is quite relevant to use for data collection in education because of its efficiency and validity [8]. This application is equipped with a quiz feature with a time limit that could be set by the teacher. Because of this simplicity, teachers prefer to use this application to compile questions that can be answered directly by the students.

\section{Edpuzzle}

Edpuzzle is an application that provides an easy ways to create questions for quiz, to send and trim videos and add voices. We can immediately view and download student scores through this application and provide information for student access to videos [9]. Teachers could send a video to their students and answer the questions listed next to the video. Students can watch the video repeatedly and pause or stop it to answer the questions. The question can be given at the end or in the middle part of the video. Teacher could also submit the questions along with the answer so that the score will be available for the teacher right after its done.

\section{Padlet}

Padlet is an application that provides a blank page that can be filled with various kinds of ideas, short writings, and summaries [10]. In addition, it also allows the user to put images and videos on the page. This app also had been used in listening classes. Teacher inserts a video, followed by a file containing questions related to the video.

\subsection{Using Applications in Learning}

Some online communication service and messaging apps such as WhatsApp, Zoom, Google Form, Edpuzzle, and Padlet had been used in BIPA Listening class for Konstanz Students. Beforehand, the teacher will creates a group chats on WhatsApp, participated by the teacher and all students. This group chats will allow the teacher to share information on the learning material, schedule, and things that need to be prepared by the students. Then the teacher will share a link for Zoom Meeting that provides schedules, Meeting ID, and passcode via this WhatsApp group. Right on the scheduled time, students will enter the Zoom Meeting and will be accepted by the teacher.

At the beginning of the Listening session, teacher will presents the learning material (PowerPoint) using the share screen feature. Then guide the students to discuss the topic. After that, teacher will provides an audio or video through Edpuzzle and asks the students to enter the Edpuzzle application by the provided link. Students will work on these tasks within the allotted time. After the students completing the task, teacher can immediately see the scores. The information on students score and processing time provided in the app. If there were unfinished tasks, the students will be able to finish it after class via Edpuzzle. Teacher will set on the working time limit. When the time limit is over, students won't be able to access the task.

Google Form and Padlet are usually used as the alternatives. Teachers will occasionally use these apps if the internet connection is unstable to view videos on Edpuzzle or to share screen via Zoom. Videos will be accessed by the students via YouTube link. Students will watch the videos on YouTube. Then the questions will be given via Google Form or Padlet. These applications also allow the teacher to easily provide the assessments. Teacher can also put comments on every answer submitted by the students.

During the Listening learning process, BIPA students could follow and use various online applications easily. It can be seen from their responses, starting from responding the WhatsApp group chats, the easiness in entering the Zoom application, and in submitting tasks on Edpuzzle, Google Form, or Padlet. Based on the outcomes from the survey, Zoom application is considered to be very easy to use and can facilitates the learning process. It is also easy for the teachers to monitor the students because it displays a clear video image. Therefore, while asking and answering questions and in discussion, it enable the teacher and students to see each other's responses.

WhatsApp is also considered an easy app to use. If there are issues on internet reception or some missing part on learning material, sending messages via WhatsApp is considered quite helpful. In addition, Edpuzzle and Google Form apps are also quite easy to use. However, one student expressed that learning via Edpuzzle did not helpful in Listening class. Unlike on other applications, three students think Padlet was less helpful for learning even though it was easy to use. It might happen because the teacher has not maximally use this app. Padlet was only used once by inserting a video and question file. Moreover, the display that looks like embedded files make it less attractive to students. The following images are the examples of the display on each apps used in this study. 


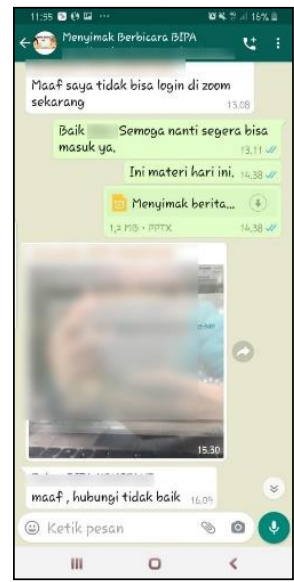

Figure 1 WhatsApp Grup

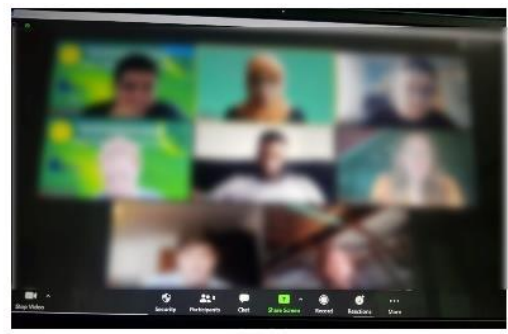

Figure 2 Zoom Meeting

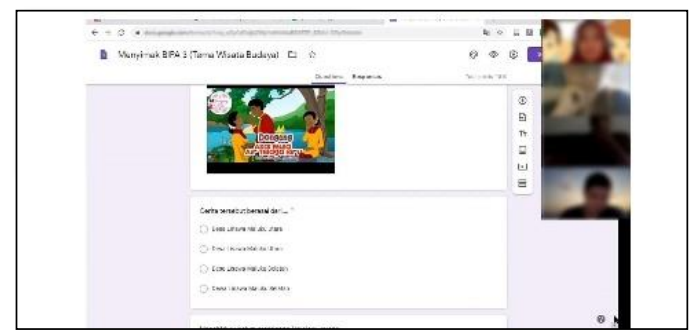

Figure 3 Google Form

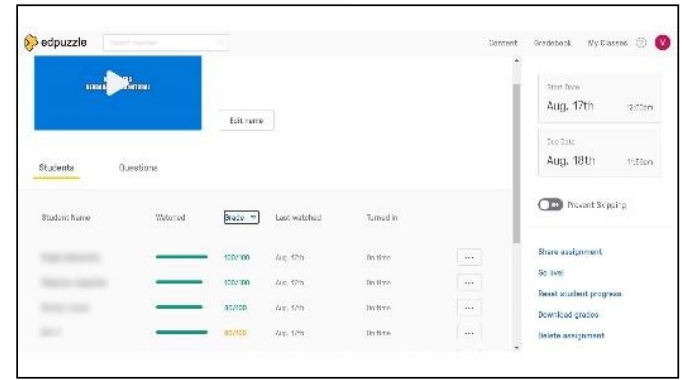

Figure 4 Edpuzzle

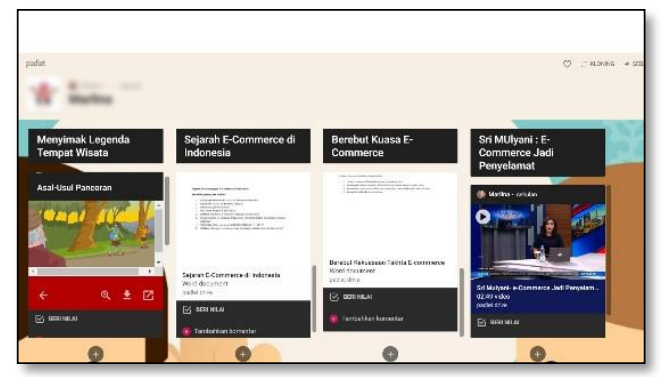

Figure 5 Padlet
After completing the learning sessions, the outcomes from the survey and the assessment during the session were analyzed. The finding reveals that during this study, the most effective app used in Listening class is Edpuzzle. On the first use, the students were unfamiliar with this app. However, on the next meeting, they already understand that this app could allow them to stop and replay the videos right on the part with added questions. It also allows the teacher to see the needed time for the students to watch the video and to complete the tasks. Edpuzzle also provide the percentage of student's time in completing the task. In addition, there is information on whether the students could finish the task on the allocated time. Based on this features, teachers could keep track of student's ability and difficulties in completing the given Listening task.

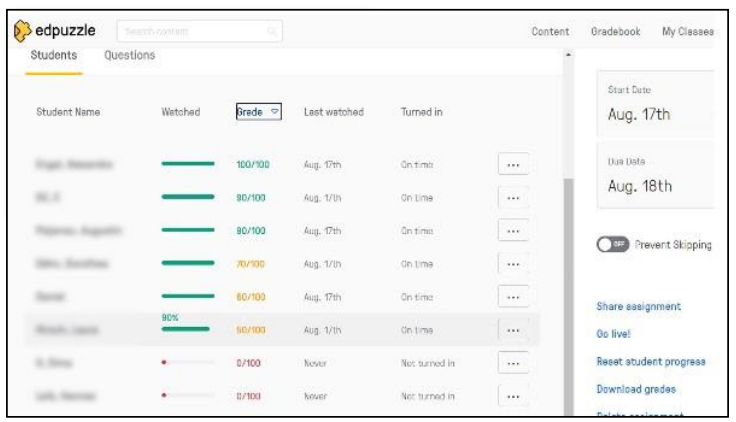

Figure 6 Edpuzzle

\subsection{The Obstacles}

The existence of various applications is quite helpful during this distance learning. However, it does not mean that there are no obstacles in the process. In this study, the teachers also give contribution by answering questions in the survey regarding the difficulties experienced by students in using online applications. The result shows that three students felt the main obstacle was the signal. One student had difficulty in understanding the instruction to use the application. One student thinks that the application was unattractive, and two students did not have any difficulties.

The quite disturbing issue was the connection or signal problem. Compared to Germany, connections in Indonesia are unstable. If the teacher plays a video directly from Zoom, the video will be very slow (buffering). If the connection is unstable, the sound that the students were supposed to be listening to was interrupted. Moreover, since they found that Indonesian native speakers speak very fast, they need a good quality audio in order to understand it. The student who stays in Lombok also experienced this connection problem. Several times he had to leave Zoom Meeting or received the message later than others due to the signal issues.

Apart from connection problems, the obstacle in virtual face-to-face learning is the student's attention and focus. Their location and learning conditions are quite 
free and relaxed. They can learn anywhere. Sometimes some students cannot participate in the whole learning activity because suddenly, there are other things that they need to do. Sometimes some students turn their video off so that the teacher cannot interact with them. Regarding this, teachers must be able to keep students to focus and pay attention during the lesson. Even in listening class, teachers need to engage the students in discussion by asking each student individually. We can ask for their feedback about the video they already watched or the questions they had just worked on.

The last obstacle is the unfinished lesson that eventually becomes their task after class. What usually happens is even after the session ends, students forgot to complete the task because they were doing something else. Teachers need to remind them via WhatsApp group repeatedly. Consequently some students were late in submitting assignments, some even did not had time to finish it, mostly if the teacher set a deadline for the task such as in Edpuzzle. Sometimes teachers have to give additional time for the students to finish the task.

The following images are the examples of the survey results.

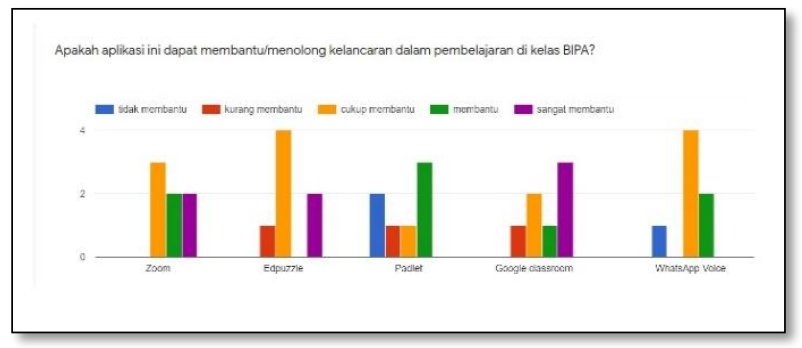

Figure 7 Survey on Student's Response on Using Applications

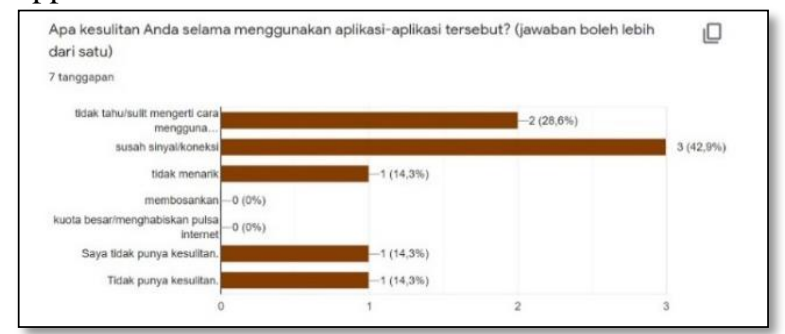

Figure 8 Survey on Student's Difficulties on Using Applications

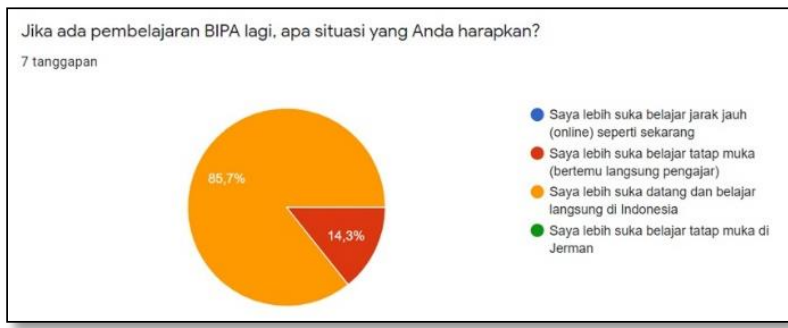

Figure 9 Survey on Student's Expectancy in the Future

\section{CONCLUSION}

Distance Learning for Listening Class requires a variety of online applications that available for streamline teaching. Online applications that have been used are WhatsApp, Zoom, Google Form, Edpuzzle, and Padlet. The study shows that the easiest to use and preferred online applications are WhatsApp and Zoom. Regarding listening questions or quizzes, the Edpuzzle application is considered more helpful for learning. However, teacher must be creative in make best use of these applications. This virtual face-to-face learning requires a higher focus than the offline one because various obstacles or disturbances might occur during lessons.

Distance learning or virtual face-to-face learning could not entirely replaced face-to-face learning in Indonesian Listening classes. The survey's outcome shows that the students prefer the offline class rather than the online one. They want to attend the class and study directly with teachers in Indonesia. Likewise, teachers also expressed that face-to-face learning cannot be replaced by the virtual face-to-face learning. Moreover, the instability of the internet network in Indonesia is still an obstacle to the effectiveness of this Distance Learning. Further, the direct interaction between teachers and students is still needed for the effective learning on Listening skill in BIPA class.

\section{REFERENCES}

[1] The Ministry of Education and Culture, Republic of Indonesia, [Online]. Available: http://bipa.kemdikbud.go.id/jaga. [Accessed September 19, 2020].

[2] J. W. Creswell, Research Design: Pendekatan Kualitatif, Kuantitatif, dan Mixed, Yogyakarta:Pustaka Pelajar, 2010.

[3] L. Muliastuti, Bahasa Indonesia bagi Penutur Asing: Acuan Teori dan Pendekatan Pengajaran, Jakarta: Yayasan Pustaka Obor Indonesia, 2017.

[4] M. Anas, Mengenal Metode Pembelajaran, Pasuruan: Pustaka Hulwa, 2014.

[5] P. Olson, "Exclusive: The Rags-To-Riches Tale Of How Jan Koum Built WhatsApp Into Facebook's New \$19 Billion Baby," Forbes, February 19, 2014. [Online]. Available:https://www.forbes.com/sites/parmyolson/2 014/02/19/exclusive-inside-story-how-jan-koumbuilt-whatsapp-into-facebooks-new-19-billionbaby/\#71abf7072fa1. [Accessed 20 September 2020].

[6] WhatsApp, "Tentang WhatsApp," 2020. [Online]. Available: https://www.whatsapp.com/about/?lang=id. [Accessed September 21, 2020]. 
[7] D. S. Dewi, "Mengenal Aplikasi Meeting Zoom: Fitur dan Cara Menggunakannya," 22 Maret 2020. [Online]. Available: https://tirto.id/mengenal-aplikasi-meetingzoom-fitur-dan-cara-menggunakannya-eGF7. [Accessed September 21, 2020].

[8] R. N. Lubis, "3 Aplikasi Guru Milenial: Menggapai Guru Masa Depan," 2019.
[9] P. V. Roehling, Flipping The College Classroom: An Evidence-Based Guide, USA: Springer, 2018.

[10] I. Kusuma, Mengajar Bahasa Inggris dengan Teknologi: Teori Dasar dan Ide Pengajaran, Yogyakarta: Deepublish, 2020. 